\title{
KOMUNIKASI MULTIKULTURAL DALAM MENJAGA KERUKUNAN ANTAR UMAT BERAGAMA DI KABUPATEN BENGKULU TENGAH
}

\author{
Rini Fitria \\ IAIN Bengkulu \\ rini@gmail.com
}

\begin{abstract}
The title of this research is Multicultural Communication in Maintaining Diversity among People of Diversity in Bengkulu Tengah Regency. The Research Team is: Rini Fitria, Japarudin and Nur Ibrahim. Research problem formulation of how multicultural communication in maintaining harmony between religious communities in Bengkulu Tengah regency. The purpose of this study is exploratory research, answering the formulation of the problem and providing solutions to understanding multicultural communication in maintaining harmony between religious communities in Sunda Kelapa and Abu Sakim villages, Pondok Kelapa subdistrict, Pondok Kelapa district, Bengkulu Tengah district. To examine these problems in depth and thoroughly, researchers used a qualitative approach with a descriptive type. Data collection methods used were participant observation, in-depth interviews and documentation studies. Analysis of the data used is triangulation. The results of the study are 1) Multicultural communication in Sunda Kelapa and Abu Sakim villages in the Cultural and Religious Studies is used effectively by the community. 2) The multicultural communication process in Sunda Kelapa and Abu Sakim villages uses a process of thoughtful sensation, perception, thinking and motivation so that harmony can be maintained well. 3) Multicultural communication in maintaining harmony between religious communities in the villages of Sunda Kelapa and Abu Sakim emphasizes religious tolerance in the form of mutual respect, respect, care, consensus and help.
\end{abstract}

Keywords: Communication, Multicultural, People, Religion.

Abstrak. Judul Penelitian ini adalah Komunikasi Multikultural dalam Menjaga Kerukunan Antar Umat Beragam di Kabupaten Bengkulu Tengah. Tim Peneliti adalah : Rini Fitria, Japarudin dan Nur Ibrahim. Rumusan masalah penelitian bagaimana komunikasi multikultural dalam menjaga kerukunan antar umat beragama di kabupaten Bengkulu Tengah. Adapun tujuan penelitian ini untuk exploratory research, menjawab rumusan masalah dan memberikan solusi pemahaman komunikasi multikultural dalam menjaga kerukunan antar umat beragama di desa Sunda Kelapa dan Abu Sakim kecamatan Pondok Kelapa kabupaten Bengkulu Tengah. Untuk mengkaji permasalah tersebut secara mendalam dan menyeluruh, peneliti menggunakan pendekatan kualitatif dengan jenis deskriptif. Metode pengumpulan data yang digunakan adalah observasi partisipan, wawancara mendalam dan studi dokumentasi. Analisa data yang digunakan adalah triangulasi. Hasil Penelitian adalah 1) Komunikasi multikultural di Desa Sunda Kelapa dan Abu Sakim dalam Kajian Budaya dan Agama digunakan secara efektif oleh 
masyarakat. 2) Proses komunikasi multikltural di desa Sunda Kelapa dan Abu Sakim lebih mengunakan proses sensasi, persepsi, berfikir dan motivasi yang bijaksana agar kerukunan tetap bisa terjaga dengan baik. 3) Komunikasi multikultural dalam menjaga kerukunan antar umat beragama di desa Sunda Kelapa dan Abu Sakim lebeih mengedepankan toleransi umat beragama berupa saling menghargai, menghormati, menjaga, musyawarah mufakat dan tolong menolong.

Kata Kunci: Komunikasi, Multikultural, Umat, Beragama.

\section{Pendahuluan}

Fenomena global masa sekarang dengan akselarasi makin tinggi seiring dengan kemajuan ilmu pengetahuan dan tekhnologi walaupun dunia dipenuhi ketegangan konflik yang ditandai dengan kekacauan hubungan antar negara, terorisme dan kolonialisme baik dari segi demografis, sosiokultural, ekonomi, tekhnologi, politik, hukum dan budaya global.

Ketika imigran berinteraksi dengan lingkungan baru yang berbeda budaya untuk jangka waktu yang lama maka akan terjadi proses resosialisai atau akulturasi. Secara bertahap imigran akan menemukan pola baru dalam pemikiran dan perilaku. Interaksi yang terjadi setiap hari dengan pribumi menyebabkan imigran memahami perbedaan dan persamaan dengan lingkungan barunya. Pendatang mulai memahami lingkungan barunya dan mengadopsi beberapa norma dan nilai masyarakat pribumi.

Dalam sejarah kebudayaan manusia proses akulturasi telah terjadi dalam masa-masa yang silam. Biasanya suatu masyarakat hidup yang bertetangga dengan masyarakat lainnya dan antara mereka terjadi hubungan-hubungan, mungkin dalam perdagangan, pemerintahan dan sebagainya. Saat menjalin hubungan tersebut akan muncul beberapa masalah, antara lain: (1) Unsur-unsur kebudayaan asing manakah yang mudah diterima; (2) Unsur-unsur kebudayaan asing manakah yang sulit diterima; (3) Individu-individu manakah yang dengan cepat menerima unsur-unsur yang baru; dan (4) Ketegangan-ketegangan apakah yang timbul sebagai akulturasi tersebut ${ }^{1}$.

Indonesia yang memiliki 34 provinsi dengan semboyan Bhinneka Tunggal Ika dari Sabang sampai ke Marauke. Memiliki ribuan pulau dengan identitas budaya masing masing yang dipertahankan secara generasi turun temurun. Salah satu Provinsi di Indonesia yaitu, Bengkulu memiliki penduduk asli pendukung kebudayaan tertua yakni; Melayu, Rejang, Serawai, Enggano. Orang Melayu merupakan kelompok etnik yang terbesar jumlahnya diantara penduduk yang bermukim di wilayah provinsi Bengkulu. Orang Melayu Bengkulu ini merupakan percampuran antara suku asli Bengkulu dengan orang-orang Melayu

\footnotetext{
${ }^{1}$ Soekanto, Sosiologi suatu pengantar, Jakarta, Raja Grafindo Persada, 1982, hal 192.
} 
pendatang dari Jambi, Riau, Palembang, Minangkabau, dan daerah-daerah lainnya di sebelah selatan ${ }^{2}$.

Pada umumnya kelompok-kelompok etnis di Bengkulu terbagi atas beberapa 'klen' (sukau) yang dikepalai oleh 'ketua sukau'. Dalam satu dusun biasanya ada 2-4 sukau. Klen ini merupakan himpunan keluarga besar yang masih seketurunan dari satu nenek moyang. Ketua sukau bersama-sama dengan kepala dusun dan para orang tua yang berhak memutuskan perkara pelanggaran adat setelah mengadakan mufakat dengan seluruh warga dusun.

Suku Rejang ini berdiam di wilayah Kabupaten Rejang Lebong yang terletak di bagian timur Provinsi Bengkulu. Wilayah tersebut mencakup sebagian pegunungan Bukit Barisan. Orang Rejang suka pula menyebut diri orang Lebong. Berasal dari kata telebong (berkumpul). menurut tambo ${ }^{3}$, mereka berasal dari Bandar Cina (Palembang) yang datang ke Pagaruyung, Sumatera Barat, dan menjadi orang Minangkabau. Sebagian lagi pergi ke lembah Ranah Sikelawi di pegunungan Bukit Barisan dan menetap di sana menjadi Orang Rejang.

Suku Serawai ini sebagian besar berdiam di Kabupaten Seluma, kecamatan Talo, Pino dan Manna di Kabupaten Bengkulu Selatan, Provinsi Bengkulu. Pada zaman dulu daerah mereka mencakup Marga Semidang Alas, Pasar Manna, Ilir Tallo, Ulu Tallo, Ulu Manna, dan Ilir Manna. Jumlah populasinya sekitar 250.000 orang. Tanah kediaman mereka cukup subur sehingga mata pencaharian pokoknya adalah bercocok tanam di sawah dan ladang. Selain bertanam padi mereka banyak membuka kebun kopi dan cengkeh. Perairan sungai dan lautnya banyak menyediakan ikan dan hasil hutannya, kayu, rotan, damar dan lain-lain cukup menguntungkan kehidupan mereka.

Suku Enggano ini berdiam di Pulau Enggano, sebelah barat pantai provinsi Bengkulu. Jumlah penduduk pulau Enggano sekitar 12.000 jiwa dan jumlah populasi suku bangsa ini di pulau tersebut sekitar 6.000 jiwa, sedangkan sisanya pendatang dari suku Batak, Minangkabau dan Jawa ${ }^{4}$.

Kebudayaan di Bengkulu yang terdiri dari berbagai etnis baik dari segi adat istiadat, bahasa dan pemaknaan, konteks bahasa, sikap. Proses mempelajari budaya adalah proses mempelajari konteks dan makna "communication (interaction) is the vehicle by which we learn how to behave and what things mean".

\footnotetext{
${ }^{2}$ Disarikan dari buku sejarah orang melayu Bengkulu, Badrul Munir Hamidy, 1980.

3 Data ini diperoleh hanya dengan pembicaraan lisan secara turun temurun yang diceritakan dalam silsilah keluarga. Dalam literatur daerah provinsi Bengkulu secara tertulis masih sulit untuk ditemukan, bahasa tertulis yang dipergunakan juga berbentuk huruf "KAGANGA" memerlukan ahli yang faham dengan bahasa tersebut, kalau percakapan sehari hari masyarakat Rejang Lebong menggunakan bahasa "Rejang” atau "Tun Jang”.

${ }^{4}$ Ibid, 1980.

5 Sthepen W Littlejohn, Theories of human communication, Wadhworth Publishing Company, Belmonth,1996, hal 16.
} 
Komunikasi multikultural terdapat sistem sosial budaya yang terbangun dengan sistem budaya yang lain. Masyarakat Bengkulu berinteraksi antarbudaya yang terdiri dari berbagai suku. Pesan yang disampaikan seolah olah dimodifikasi dengan cara adanya perbauran bahasa yang digunakan, orang Melayu terkadang memahami bahasa Rejang, orang Serawai juga bisa menggunakan bahasa Melayu Bengkulu sehingga pesan yang disampaikan seolah olah telah milik bersama. Namun tidak semua masyarakat Bengkulu bisa menggunakan tiga bahasa tersebut, apalagi masyarkat pendatang. Karena bahasa tersebut dari segi intonasi, ucapan dan arti berbeda beda. Budaya di Bengkulu terdiri dari berbagai unsur baik upacara perkawinan, persedekahan, ekonomi, agama, politik dan lain lain yang masyarakatnya multietnis.

Berbagai budaya yang ada di Bengkulu terkadang menyebabkan adanya potensi potensi konflik yang terjadi, berdasarkan data sementara yang diperoleh konflik antarumat beragama, ekonomi, politik dan budaya. ${ }^{6}$ Konflik yang terjadi ini bisa berakhir dengan baik dan damai, tentunya proses komunikasi multikultural ini sangat perlu difahami oleh setiap individu. Agar komunikasi yang terjadi tidak menyebabkan salah akan pemaknaan pesan yang disampaikan melalui berbagai media baik, politik, ekonomi, sosial, dan budaya.

Di Kabupaten Seluma terdapat suku Sunda dan Jawa yang menenetap bahkan ada daerah 'babatan solok' yang didirikan akan tetapi perpaduan dengan suku asli yang ada di Bengkulu tetap terjalin dengan baik. Di Kabupaten Bengkulu Utara di daerah Rama Angung terdapat multikultur agama dan budaya, daerah transmigrasi orang Bali, Jawa dan agama yang beragam namun tetap bisa hidup berdampingan dengan harmonis dengan penduduk asli yang ada. Di provinsi Bengkulu kehidupan multikultural terjaga dengan baik bahkan tidak ada penonjolan keberadaan suku mana yang lebih dominan. Kabupaten Bengkulu tengah yang memiliki perbatasan dengan sebelah Utara: Kecamatan Air Napal. sebelah selatan: Kota Bengkulu. Sebelah barat: Samudra Indonesia dan Sebelah Timur: Kecamatan Talang Empat, Kecamatan Pagar Jati dan Kecamatan Pematang Tiga.

Tiga rumpun suku besar yang ada Kabupaten Bengkulu Tengah adalah: Suku Rejang umumnya tinggal di Kecamatan Taba Penanjung, Kecamatan Karang Tinggi, Pagar Jati, dan Kecamatan Pematang Tiga sedangkan Suku Lembak umunya tinggal di Kecamatan Talang Empat, Karang Tinggi dan Kecamatan Pondok Kelapa dan Suku Jawa umumnya tinggal di Kecamatan Pondok Kelapa, Pagar Jati dan Kecamatan Talang Empat.

\footnotetext{
${ }^{6}$ Konflik antarumat beragama ini terjadi karena aturan pendirian rumah ibadah, pada tahun 2002 pendirian rumah ibadah umat Kristiani di pemukiman umat Islam dan jumlah penduduk kritiani belum mencapai batas minimal pendirin rumah ibadah, masih ditahun yang sama adanya konflik yang di latarbelakangi ekonomi. Pada tahun 2015 adanya konflik politik mengenai tapal batas Kabupaten Bengkulu Utara dengan Kabupaten Lebong dan antara Kabupaten Rejang Lebong dengan Kabupaten Kepahiang. Dalam budayapun konflik pelaksana ritual Tabot.
}

${ }^{7}$ BPS Bengkulu Tengah, tahun 2016 
Bahasa yang digunakan dalam pergaulan sehari-hari untuk antar suku umumnya menggunakan bahasa Melayu Bengkulu sebagai bahasa komunikasi selain bahasa Indonesia. Untuk komunikasi sesama suku menggunakan bahasa daerah masing-masing suku. Seperti Bahasa Rejang, Bahasa Lembak, Bahasa Serawai, Bahasa Jawa, Bahasa Sunda dan lain- lain.

Pengaruh Agama Islam dalam kehidupan sehari-hari masyarakat Bengkulu Tengah masih sangat kental, hal ini terlihat seperti dalam upacara perkawinan, Kesenian Syarafal Annam dan Kesenian Rebana dan nyanyian-nyanyian berirama padang pasir.

Salah satu kecamatan yang ada di wilayah Bengkulu tengah ini adalah Kecamatan pondok Kelapa ${ }^{8}$ dan salah satu desa adalah desa Sunda Kelapa dan desa Abu Sakim. Berdasarkan observasi awal yang dilakukan oleh peneliti di dua desa ini terdapat kemajemukan budaya, adat istiadat dan agama.

Desa Sunda kelapa dan Abu Sakim merupakan daerah transmigrasi dari beberapa wilayah di Indonesia yaitu dari Bali yang mayoritas menganut agama Hindu', dari daerah Bugis, Palembang, Jawa dan penduduk Asli suku Lembak.

Desa Sunda Kelapa terdapat tiga agama yang dianut yaitu Islam, Hindu dan Kristen. Sedangkan di desa Abu Sakim terdapat dua agama yaitu agama Kristen dan Islam ${ }^{10}$.

\section{Sejarah Desa Abu Sakim}

Desa Abu Sakim berasal dari "Dusun Abu Sakim". Nama Abu Sakim berasal dari nama seorang petugas pengawas (mandor) jalan yang bernama “ Bapak Abu Sakim “ yang berasal dari Kabupaten Kepahiyang yang juga seorang tentara. Awalnya Abu Sakim itu sebutan untuk jalan yang dibangun tersebut agar mudah diingat. Dulunya Desa Abu sakim itu merupakan bagian dari Dusun Tegah/Sunda Kelapa pada tahun 1973 dan mayoritas penduduknya berasal dari transmigrasi dari Jakarta. Sunda Kelapa Awalnya terbagi atas 5 dusun, yaitu : Dusun I (Sungai Kotong I), Dusun II ( Kampung Tengah), Dusun III (Abu Sakim), Dusun IV (Sungai Kotong II), Dusun V (Talang Kedurang).

Pada tahun 2010 pemekaran Kabupaten yang ada di provinsi Bengkulu, diantaranya Bengkulu Tengah, sehingga Desa Abu Sakim merupakan

\footnotetext{
${ }^{8}$ Dalam catan buku BPS Bengkulu tengah tahun 2016 Kecamatan Pondok kelapa ini memiliki 17 desa.

${ }^{9}$ Hasil observasi awal peneliti, membedakan ciri khas dari bentuk artefak, maka di setiap rumah penduduk yang berasal dari Bali memiliki rumah ibadah berbentuk pura ibadah yang dibangun di depan rumah penduduk ada yang sederhana dan adapula yang terbangun dengan megah. Sedangkan rumah penduduk lain yang tidak beragama Hindu, maka di depan rumahnya tidak terdapat rumah ibadah. 28 Januari 2017.

${ }^{10}$ Hasil observasi awal desa Abu Sakim ini mayoritas agama penduduk desa adalah Islam yang menganut dua aliran islam yang disebut dengan aliran Nahdlatul Ulama (Islam NU) dan Islam As-Syidiqiyah, bahkan berdasarkan informasi warga setempat pada Tahun 2016 lalu, umat Islam di desa Abu Sakim ini melaksanakan hari Raya Idhul Fitri berbeda waktunya, 28 Januari 2017
} 
pemekaran dari desa Sunda Kelapa. Maka Dusun Abu Sakim dan Talang Kedurang menjadi 1 Desa yaitu Desa Abu Sakim. Mulai dari itu Desa Abu Sakim dipimpin oleh Bapak Pirmanto Sebagai Kepala Desa yang menjabat periode 2010-2018.

\section{Keadaan Penduduk}

Berdasarkan hasil pengamatan observasi dan pengumpulan data Profil Desa, Desa Abu Sakim kecamatan Pondok Kelapa kabupaten Bengkulu Tengah Provinsi Bengkulu menerangkan bahwa keadaan sosial Desa Abu Sakim penduduknya memiliki etnis yang bermacam-macam seperti Bugis, Jawa, Sunda, Batak, Rejang, Serawai, Bengkulu Selatan, Palembang dan lain lain, akan tetapi walaupun memiliki etnis yang berbeda masyarakat Desa Abu Sakim hidup dengan aman dan tentram. Hal ini dapat dilihat dari partisipasi masyarakat dalam berbagai macam kegiatan seperti pembuatan sarana dan prasarana peribadatan, perayaan HUT RI dan Perayaan Hari Besar Islam (PHBI) salah satu'nya peringatan Nuzulul Qur'an. Sifat tolong-menolong antar masyarakat sangat erat dan juga kesadaran masyarakat Desa Abu Sakim cukup tinggi. Masyarakat Desa Abu Sakim juga cukup aktif dalam Organisasi Kemasyarakatan, Dapat dilihat dari Organisasi yang telah terbentuk seperti: Karang Taruna, RISMA, Majelis taklim dan Kelompok Tani.

Keadaan Sosial Pendidikan

Keadaan sosial pendidikan Desa Abu Sakim saat ini sudah cukup baik. Karena di Desa Abu Sakim telah memiliki 1 gedung PAUD dan 1 gedung SD. Mayoritas anak disana berstatus pelajar. Jenjang pendidikan masyarakat desa banyak yang berstatus diploma dan sarjana. Dapat dilihat pada tabel 3 di atas.

\section{Keadaan Kehidupan Keagamaan Islam}

Penduduk Desa Abu Sakim mayoritas menganut Agama Islam. Adapun sarana tempat peribadatan yang ada di Desa Abu Sakim yaitu Masjid 2 unit dan surau 3 sedangkan tempat peribadatan Agama lain di Desa Abu Sakim tidak ada. Walaupun demikian penduduk Desa Abu Sakim yang mayoritasnya beragama Islam, masyarakatnya juga kuat dalam bidang keagamaan. Seperti pelaksanaan shalat berjamaah di Masjid, mengikuti pengajian rutin. Sedangkan pendidikan keagamaan di Desa Abu Sakim banyak, seperti adanya TPA, namun belum berjalan seperti yang diharapkan. Anak-anak Desa Abu Sakim sangat kuat semangatnya untuk mengaji yang biasanya dilakukan pada sore hari di TPA maupun mengaji di masjid. Berikut ini jumlah penduduk berdasarkan Agama yang dianut di desa Abu Sakim.

\section{Letak Geografis Desa Sunda Kelapa}

Desa Sunda Kelapa terletak dikecamatan Pondok Kelapa Kabupaten Bengkulu Tengah Provinsi Bengkulu dengan luas \pm 1500 ha. Secara 
administrasi batas-batas Desa Sunda Kelapa II dapat dilihat pada tabel 6 berikut ini :

Tabel 2

\begin{tabular}{|c|ll|}
\hline Batas & \multicolumn{2}{|c|}{ Desa/kelurahan } \\
\hline Barat & $\begin{array}{l}\text { Berbatasan dengan Sungai } \\
\text { Limau }\end{array}$ \\
\hline Timur & $\begin{array}{l}\text { Berbatasan dengan Desa } \\
\text { Sidorejo }\end{array}$ \\
\hline Utara & $\begin{array}{l}\text { Berbatasan dengan Desa } \\
\text { Abusakim }\end{array}$ \\
\hline Selatan & $\begin{array}{l}\text { Berbatasan dengan Desa } \\
\text { Pondok Kelapa }\end{array}$ \\
\hline
\end{tabular}

Desa yang memiliki luas wilayah +1.500 ha ini meliputi 3 Dusun/Rukun Tetangga dengan perincian sebagai berikut : Dusun Sungai Kotong Luar, Dusun Sungai Kotong Dalam, Dusun Kampung Tengah.

Tabel 3

\begin{tabular}{|l|c|l|}
\hline No & Pra sekolah & 288 orang \\
\hline 1 & SD & 263 Orang \\
\hline 2 & SLTP & 301 Orang \\
\hline 3 & SLTA & 339 Orang \\
\hline 4 & SARJANA & 25 Orang \\
\hline 5 & DIPLOMA & 33 Orang \\
\hline
\end{tabular}

Sumber: Dokumntasi Kantor Desa Sunda Kelapa tahun 2016

Tabel 3 di atas menunjukkan bahwa penduduk tamat SD sebesar 698 jiwa dengan presentase sebesar sebesar 69\%. Jadi dapat ditarik kesimpulan bahwa masyarakat desa Sunda Kelapa sudah dapat mengenal huruf dan angka secara keseluruhan. Desa Sunda Kelapa yang memiliki luas wilayah \pm 1500 ha ini mempunyai perincian penggunanaan lahan, yang mana perincian tersebut dapat dilihat pada tabel 11 berikut ini : 
Tabel 4

\begin{tabular}{|l|l|l|}
\hline No & Penggunaan Lahan & Luas Lahan \\
\hline 1 & Sawah & $30 \mathrm{ha}$ \\
\hline 2 & Perkebunan & $1.382 \mathrm{ha}$ \\
\hline 4 & Tanah kering & $84 \mathrm{ha}$ \\
\hline 5 & Tanah rawa & $4 \mathrm{ha}$ \\
\hline
\end{tabular}

Sumber : Kantor Desa Sunda Kelapa tahun 2016

Tabel tersebut menunjukkan bahwasanya Desa Sunda Kelapa Kecamatan Pondok Kelapa Kabupaten Bengkulu Tengah yang memiliki luas 1500 ha, Mempunyai rincian penggunaan lahan yaitu, sawah 30 ha, perkebunan 1.382 ha, tanah kering 84 ha, tanah rawa 4 ha.

Untuk sarana perhubungan yang lazim digunakan oleh masyarakat Desa Sunda Kelapa adalah menggunakan Transportasi Darat ( mobil dan motor). Prasarana/ jalan yang menghubungkan Desa Sunda Kelapa dengan yang lain di katakana baik karena telah di aspal sehingga jalannya tidak becek ketika hujan turun.

Penduduk Desa Pagar Agung terdiri Dari bermacam-macam suku atau etnis, diantaranya penduduk bersuku jawa, sunda, bugis, dan serawai. Namun mayoritas penduduk bersuku Jawa, hanya sebagian kecil yang bersuku sunda, jawa,Bali, bugis. Penduduk asli Desa Sunda Kelapa adalah Suku Bali, Jawa, Sunda, Yogyakarta, Bugis, Palembang, Lembak dan Lampung. Sehingga terjadi percampuran dan kerjasama diantara penduduk asli dan pendatang, seperti gotong royong dan kearifan lokal yang di jalin untuk menghindari adanya benturan ataupun konflik sosial yang penduduknya mayoritas beragama islam.

Kondisi ekonomi masyarakat Desa Sunda Kelapa Kecamatan Pondok Kelapa Kabupaten Bengkulu Tengah secara kasat mata dapat dilihat bahwa masyarakat Desa Sunda Kelapa terlihat jelas perbedaannya antara Rumah Tangga yang berkategori miskin, sangat miskin, sedang dan kaya. Hal ini disebabkan karena mata pencahariannya di sektor-sektor usaha yang berbedabeda pula, sebagian besar di sektor non formal seperti petani, pedagang, buruh tani, dan di sektor formal seperti PNS pemda, honorer, guru, tenaga medis.

Penduduk Desa Sunda Kelapa Kecamatan Pondok Kelapa Kabupaten Bengkulu Tengah 85\% beragama Islam dan 10\% lagi beragama Hindu dan 5\% Protestan. Masyarakat Sunda Kelapa sering melakukan kegiatan agama secara bersama-sama seperti yasinan, memperingati hari besar Islam, dan sebagainya, begitu juga dengan yang agama lainnya mereka melakukan ritual agama nya masing-masing. Akan tetapi sholat berjamaah belum berjalan dalam lima waktu ke masjid di karenakan mayoritas masyarakat Desa tersebut kepedulian pemuda 
dan anak-anak terhadap agama sudah ada meskipun belum seluruhnya. TPQ sudah ada akan tetapi anak-anak banyak yang belajar mengaji kerumah imam, sehingga mereka sedikit banyak sudah mulai mengerti baca tulis al-quran. Ada juga dari sebagian besar anak-anak yang belum bisa baca tulis al-quran hal ini di sebabkan oleh kurangnya kesadaran anak-anak, keterbatasan tenaga pengajar dan dana pembangunan sarana prasarana.

\section{Keadaan Sosial Budaya}

Penduduk diwilayah ini terdiri dari beberapa suku yaitu, Bali, jawa, sunda, dan bugis, namun mayoritas penduduk tersebut bersuku Jawa. Oleh karena itu dalam kehidupan sehari-harinya, masyarakat menggunakan bahasa Jawa dalam berkomunikasi.

Kegiatan budaya sudah sangat tampak diantaranya cara masyarakat menerima tamu dirumah mereka. Biasa tamu yang datang dilayani dengan hormat sebagaimana mestinya, tamu yang datang disuguhi minuman dan makanan. Pada saat datangnya bulan ramadhan masyarakat mengadakan syukuran dan bergotong royong membersihkan pemukiman. Masyarakat sangat menjaga kebudayaan tersebut.

Dalam acara kematian, di desa Sunda Kelapa ini tetap mengadakan sebagaimana kewajiban seorang manusia jika sesama hamba Allah SWT mendapatkan musibah, dengan mengadakan pengajian dan doa yang mana tidak memberatkan orang yang terkena musibah tersebut. Masyarakat desa Sunda Kelapa ini mengadakan yasinan dan juga doa mulai malam 1, ke 3, 7, 40, dan 100 malam pertama dan kedua mereka masih tetap ramai untuk berkunjung kerumah ahli musibah tetapi untuk malam selanjutnya mereka harus memanggil kepada warga untuk datang kerumahnya, secara religius apabila ada yang terkena musibah kita sebagai hamba Allah SWT sudah dianjurkan untuk menjenguknya guna untuk meringankan, menghibur dan mendoakan bagi yang terkena musibah.

\section{Hasil dan Pembahasan}

Jika kita menelusuri jalan poros dari kota Bengkulu menuju Bengkulu Tengah maka kita akan menemukan Jalan Sidodadi terdapat desa Sunda Kelapa dan Desa Abu Sakim di desa Abu Sakim terdapat dua agama yang dianut oleh masyarakat mayoritas yaitu agama Islam dan sebahagian kecil jumlah masyarakat beragama Kristen, sedangkan rumah ibadah di desa ini Masjid terdapat 2 rumah ibadah dan satu mushallah. Sedangkan umat Kristen melaksanakan peribadatan di desa Pekik Nyari yang terdapat di luar desa Abu Sakim, berdasarkan hasil wawancara yang tim peneliti lakukan, Bapak Edy 
Purnomo mengatakan " di desa ini tidak terdapat gereja, jika kami akan melaksanakan peribadatan maka kami keluar desa di desa Pekik Nyaring",11

Desa Abu Sakim yang merupakan tempat transmigrasi masyarakat dari pulau Jawa dan Lampung. Ada masyarakat yang dari Bengkulu Selatan yang berada di desa ini sehingga di sebut Kampung Selatan. Desa Abu sakim dari segi inprastruktur pembangunan desa sudah sangat baik,salah satu ukuran baik dan tidak bisa dilihat dari jalan yang dilalui di sepanjang desa. Jalan desa Abu Sakim ini sudah beraspal namun dalam proses penelitian atau survey awal memang desa Abu Sakim masih berupa jalan bebatuan dan dalam proses pengasapalan.

Desa Abu Sakim jika dilihat dari perumahan masyarakatnya maka akan terlihat dalam masyarakat memiliki pendapatan yang berkecukupan, dilihat dari dalam desa perkebunan kelapa sawit. Ketika tim peneliti wawancara dengan masyarakat mengatakan " masyarakat desa Abu Sakim rata rata merupakan petani kelapa sawit dan dan Petani Karet"12. Desa Abu Sakim memiliki perbedaan dengan desa Sunda Kelapa pada umat beragamanya saja, desa Abu Sakim memiliki mayoritas umat Islam, ada yang menarik di desa ini bagi masyarakat yang tidak memiliki rumah untuk tempat tinggal maka ada aliran As Syidiqiyyah akan memberikan bantuan untuk mendirikan rumah sederhana dengan persyaratan orang yang akan dibangunkan rumah harus memiliki tanah sebagai lahan untuk tempat pembangunan hal ini di jelaskan oleh bapak Badarudin, sebagai berikutl; " kami di desa Abu Sakim akan membantu masyarakat dalam berbagai bentuk salah satunya membangun rumah bagi yang belum memiliki tempat tinggal dengan syarat masyarakat tersebut tidak memiliki rumah dan menyediakan tanah sebagai lahan pembangunan nantinya"13

Bedasarkan hasil observasi yang dilakukan oleh tim peneliti di desa Abu Sakim terdapat bebrapa bangaunan rumah yang memiliki bentuk dan warna yang sama, bahkan terdapat tulisan di bagian atas teras rumah tersebut, meruapakan hasil pembangunan dari aliran Asy-Syidiqiyyah.

Dari desa Abu Sakim jika akan kearah kota Bengkulu maka kita akan sampai ke desa Sunda Kelapa. Dari pintu gerbang Abu Sakim menuju Sunda Kelapa maka kita akan di sambut dengan tempat peribadatan "pura" umat Hindu yang berada disetiap rumah penduduk, pemandangan rumah ibadah ini sangat tertata dengan baik, setiap rumah bagi umat Hindu akan membangun rumah ibadah sendiri di halaman rumah mereka dengan cat warna warni di sesuaikan dengan kkeinginan pemilik rumah, termasuk besar atau kecil pura tersebut.

Dalam perjalanan tim peneliti menghampiri salah satu rumah warga desa Sunda Kelapa yang pada saat itu sedang mempersiapkan hari ulang tahun rumah

\footnotetext{
${ }^{11}$ Wawancara dengan Bapak Edy Purnomo, tokoh Agama Kristen Protestan Desa Abu Sakim Kecamatan Pondok Kelapa Kabupaten Bengkulu Tengah pada tanggal 22 Juli 2017.

${ }^{12}$ Wawancara dengan Bapak Parno, masyarakat desa abu Sakim pada tanggal 22 Agustus 2017.

${ }^{13}$ Wawancara dengan Bapak Badarudin, tokoh masyarakat desa Abu Sakim pada tanggal 22 Agustus 2017.
} 
ibadah, kesempatan ini tim peneliti anggap sangat baik untuk wawancara dengan pemilik rumah dalam proses persiapan ulang tahun rumah ibadah ini, pemilik rumah ibadah mengatakan: "kami mempersiapakan ulang tahun rumah ibadah ini setiap 5 tahun sekali, terutama daun kelapa muda yang dibentuk dan beberapa bunga hidup yang diambil dan tidak boleh jatuh atau terlangkah kaki manusia, tanaman bunga yang tidak di atasnya ada benda lain misalnya jemuran pakaian." ${ }^{14}$

Jika menyusuri jalan maka di depan rumah mayoritas penduduknya beragama Hindu maka akan terlihat rumah ibadah "pura" di halaman rumah mereka. Jika kita menyusuri bagian belakang desa maka kita akan memperoleh pemandangan yang berbeda pula, sudah ada ke bhinekaan, perbauran penduduk yang berasal dari berbagai daerah terlihat, tidak hanya rumah ibadah berupa "pura" saja akan tetapi akan di temukan rumah ibadah umat Islam yaitu masjid, di desa Sunda Kelapa terdapat dua Masjid dan satu Pura Kecamatan Pondok Kelapa.

Dalam kehidupan sehari hari masyarakat di desa Abu Sakim dan Desa Sunda Kelapa ini selayaknya masyarakat di bumi Indonesia yang hidup rukun damai. Peneliti akan mewawancarai sejumlah orang yang masuk dalam kategori purposive sampling yaitu orang yang tim peneliti tentukan berdasarkan beberapa kriteria, adalah:

1. Masyarakat yang berdomisili di desa Abu Sakin atau Sunda Kelapa kecamatan Pondok Kelapa Kabupaten Bengkulu Tengah,

2. Masyarakat yang memahami proses komunikasi di desa Abu Sakim atau Desa Sunda Kelapa.

3. Masyarakat yang memiliki jabatan sebagai tokoh adat, agama atau perangkat desa.

4. Masyarakat yang bersedia memberikan tanggapan dengan wawancara yang di lakukan secara baik dan benar.

Berdasarkan hasil observasi yang dilakukan oleh tim peneliti di desa Abu Sakim dan desa Sunda Kelapa dengan menyusuri jalan dari Kampung Tengah yang masuk kedalam desa Sunda Kelapa melihat keadaan desa sampai keperkampungan desa Abu Sakim. Dalam observasi ini tim peneliti dapat menentukan siapa yang akan ditemui terlebih dahulu agar dapat menentukan informan kunci dalam penelitian ini, maka tim peneliti melakukan wawancara dengan Kepala Desa dan masyarakat, maka peneliti menyimpulkan beberapa nama orang yang peneliti gambarkan dalam tabel berikut ini:

Informan penelitian berjumlah 15 orang terdiri dari: dua orang Kepala desa 2 orang perangkat desa, 1 orang Tokoh Adat, 4 orang tokoh agama, 2 orang tokoh masyarakat dan 3 orang masyarakat desa. Berdasarkan kriteria purposive sampling maka informan penelitian ini layak dan valid untuk di wawancara.

\footnotetext{
${ }^{14}$ Wawancara dengan ibu Ida, pemilik rumah ibadah yang akan berulang tahun, desa Sunda Kelapa pada tanggal 22 Agustus 2017.
} 
Desa Abu Sakim dan Sunda Kelapa yang terediri beberapa agama yaitu: Islam, hindu dan Kristen. Memiliki beberapa suku yaitu, Sunda, Jawa Tengah, Jawa Timutr, Lampung, Sulawesi, Cirebon, Palembang, Bali dan Bengkulu $(\text { Lembak })^{15}$. Dalam pelaksanaan ritual keagamaan yang dilaksanakan sehari hari maupun dalam perayaaan hari besar dalam agama masing masing tentunya dilaksanakan dengan penuh rasa tanggung jawab.

Desa Abu Sakim dan Desa Sunda Kelapa adalah daerah yang berdekatan bahkan dahulunya adalah satu desa yaitu Desa Sunda Kelapa yang berdiri sejak tanggal 9 Desember 1973 kemudian terjadi diproses menjadi dua desa yaitu desa Sunda Kelapa dan Desa Abu Sakim pada tahun 2010 ${ }^{16}$.

Perayaan Hari hari besar yang dilaksankan dalam agama di desa Sunda Kelapa dan Abu Sakim menurut beberapa informan yaitu:

"dalam agama Islam tentunya seperti hari raya Idbul Fitri dan idul Adha dilaksanakan pada setiap tabun dan Mauludan serta isra mi'raj".

Perayaan hari besar umat Islam di desa Sunda Kelapa dan Abu Sakim berdasarkan perhitungan tahun bari Hijriah atau pertanggalan umat Islam. Perasaan ini dilangsungkan dengan baik dan saling menghormati antar umat beragama. jika pada saat perayaan seperti bertepatan dengan hari yang sama terjadi dengan umat lain seperti hindu dan Kristen maka perayaan dilangsungkan dengan kesepakatan antar umat beragama yang dengan musyawah untuk mencapai muafak bersama, seperti yang di kemukakan oleh bapak Sri Widodo salah seorang pemuka adat dari agama Islam mengatakan bahwa:

"jika terjadi pelaksanaan yang bertepatan dengan kegiatan agama lain, maka perayaan di musyawarabkan bersama sama dengan poemuka agama, adat dan perangkat desa"18

Pernyataan bapak Sri Widodo yang bertempat tinggal di Desa Sunda Kelapa tidak jauh beda pendapat bapak Pirmanto sebagai Kepala Desa Abu Sakim mengatakan, bahwa: "Tika ada perayaan yang sama harinya dengan agama lain maka akan diadakan musyawarah untuk mencapai mufakat antar tokoh agama, adat dan perangkat desa agar tetap terjaga kerukunan di sini"1?.

Data ini perlu di konfirmasi dengan Bapak Edy Purnomo, agar data yang didapatkan tentunya valid dan dapat dipertanggung jawabkan, menurut beliau "memang benar jika ada perayaan yang waktunya bersamaan dengan agama lain, maka

${ }^{15}$ Data dokumentasi desa Sunda Kelapa dan Desa Abu Sakim Kecamatan Pondok Kelapa Kabupaten Bengkulu Tengah dan dari hasil Focus Group Discussion di desa Sunda Kelapa, 31 Juli 2017.

${ }^{16}$ Data hasil wawancara dengan Bapak Karyo sebagai Kepala Desa Sunda Kelapa dan Bapak Pirmanto sebagai Kepala Desa Abu Sakim pada tanggal 10 Juli 2017

${ }^{17}$ Wawancara dengan beberapa informan penelitian yang beragama Islam di desa Sunda Kelapa dan Abu Sakim, pada tanggal 16 Juli 2017.

${ }^{18}$ Wawancara dengan Bapak Sri Widodo Pemuka adat Desa Sunda Kelapa, pada tanggal 7 Agustus 2017.

${ }^{19}$ Wawancara dengan Bapak Pirmanto, Kepala Desa Desa Abu Sakim Kecamatan Pondok Kelapa Kabupaten Bengkulu Tengah pada tanggal 7 Agustus 2017. 
akan diadakannya musyawarah untuk mencapai kata mufakat, hal ini dilakukan agar tetap terjaga keharmonisan antar agama dan suku di desa ini,20.

Berdasarakan hasil wawancara dengan beberapa orang informan dan data dokumentasi desa Abu Sakim dan Desa Sunda Kelapa dalam urusan ritual keagamaan dan perayaan hari besar agama masing masing tidak terjadi perselisihan faham, bahkan masyarakat di dua desa ini saling menghormati bahkan saling menghargai peribadatan masing masing agama.

\section{Komunikasi multikultural di Desa Sunda Kelapa dan Abu Sakim dalam Kajian Budaya dan Agama.}

Perspektif pertama komunikasi multikultural bertitik tolak pada kajian komunikasi yang memfokuskan diri pada proses komunikasi secara interaksional dan transaksional partisipan. Komunikasi masyarakat desa Abu Sakim dan Sunda Kelapa akan dilihat dari proses mereka berkomunikasi dengan melihat multikultural di dalamnya. Kajian konteks budaya dan agama menjadi urgen.

Kebudayaan yang dianut oleh suatu masyarakat sangatlah unik. Bahasa, cara makan, cara berpakaian, cara sopan santun, standar moral, dari suatu komunitas berbeda dengan komunitas yang lain. Kebudayaan juga disebut dengan communicable knowlage artinya bahwa kebudayaan merupakan proses pembelajaran yang dipelajari oleh setiap anggota masyarakat dengan partisivasi dan pertukaran antar kelompok sosial sebagaimana termanifestasi dalam situasi dan artefak.

Cara belajarpun dalam budaya sangatlah kompleks, termasuk ilmu pengetahuan, kepercayaan, seni, moral, hukum, adat kebiasaan, yang diterima oleh anggota masyarakat. Setiap anggota masyarakat memproduksi jawabannya sendiri yang khusus dalam menghadapi kehidupan seperti, kelahiran, pertumbuhan, hubungan sosial bahkan kematian. Seperti yang dituturkan oleh bapak Wayan Sujana yang beragama Hindu;

"Kami juga melaksanakan ritual keagamaan seperti Nyepi untuk menumbuhkan rasa keagamaan atau Kuningan. Bahkan ketika perayaan Saraswati bisa dilakukan setiap minggu" 21

Tentunya perayaan yang dilakukan juga diperbolehkan untuk mengundang atau jika ada agama lain yang ingin mengikuti, misalnya acara perayaan Galungan yang dilakukan di pantai Pondok Kelapa. Jika umat Islam atau Kristen ingin melihat di perbolehkan, seperti yang di sampaikan oleh bapak I Dewa Gede Ardana:

"Kami merayakan hari raya Galungan dari pagi sampai siang, biasanya ada umat agama lain menonton,"22

20 Wawancara dengan Bapak Edy purnomo tokoh agama yang beragama Kristen Protestan, di desa Abu Sakim Kecamatan Pondok Kelapa Kabupaten Bengkulu Tengah pada tanggal 14 Agustus 2017

${ }^{21}$ Wawancara dengan Bapak Wayan Sujana, Tokoh Agama Hindu desa Abu Sakim, 8 Agustus 2017. 
Dalam proses pemebelajaran tersebut, maka setiap anggota masyarakat akan memberikan kontribusi terhadap suatu kebudayaan dalam evolusi sosial, meskipun tidak dapat dihindari perkembangan setiap kebudayaan itu dari suatu masyarakat dengan masyarakat lain berbeda beda. Inilah mengapa kebudayaan menjadi identitas suatu masyarakat

Kajian komunikasi multikultural adalah studi tentang proses mental, yang mana setiap partisipant tindak komunikasi menyalurkan gagasan, penalarannya dan pendekatan sebagai suatu kehendak natural setiap orang agar pesan yang disampaikan mampu difahami oleh orang lain. Namun tidak semua orang mutlak memiliki pengertian yang sama tentang budaya orang lain. Hal ini disebabkan adanya ketertutupan terhadap budaya lain atau keengganan budaya asing masuk kedalam budaya.

Jadi setiap orang harus dilihat dari individu dengan pola fikir yang khas dan berbeda beda. Sama sama orang Bengkulu tapi memiliki pola fikir yang brbeda beda ibarat pepatah "rambut sama hitam tapi fikiran tidaklah sama".

Perbedaan pola fikir ini mengakibatkan manifestasi kehidupan sehari hari sangat berbeda pula terhadap, reaksi, rangsangan dan respons individu dalam tindakan komunikasi dari komunkan dari budaya yang berbeda. Sehingga pendekatan yang dilakukan dalam komunikasi multikultural ini adalah kesadaran bahwa pola berfikir setiap partisipan komunikasi dapat dipelajari dalam aktivitas sosialnya sehingga ada kesempatan belajar dan saling mengenal budaya orang lain. Dalam aplikasi kehidupan bermasyarakat baik desa Abu Sakim maupun desa Sunda Kelapa perayaan agama apapun tentunya saling menghormati dan saling menghargai.

Etnosentrisme adalah adalah egoisme cultural, sekelompok masyarakat beranggapan dirinya paling superior diantara yang lain, penilaian budayanya sendiri yang lebih baik. Jadi etnosentrisme itu penghakiman suatu kelompok masyarakat terhadap kebudayaan masyarakat lain dengan cara membandingkan atau menggunakan standar kebudayaan sendiri.

Semua penilaian berangkat dari ukuran budaya sendiri menyebabkan apa yang baik adalah budaya sendiri, sedangkan udaya orang lain dianggap lebih rendah. Jika seteriotipe penilaian "dirinya paling superior diantara yang lain, penilaian budayanya sendiri yang lebih baik. Jadi etnosentrisme itu penghakiman suatu kelompok masyarakat terhadap kebudayaan masyarakat lain dengan cara membandingkan atau menggunakan standar kebudayaan sendiri.

Semua penilaian berangkat dari ukuran budaya sendiri menyebabkan apa yang baik adalah budaya sendiri, sedangkan udaya orang lain dianggap lebih rendah. Jika seteriotipe penilaian "salah kaprah" etnosentrisme penilaian "membabi buta".

Saling menghormati antar kebudayaan sangatlah penting seperti diungkapkan oleh kepala desa Sunda Kelapa bapak Karyo:

22 Wawancara dengan Bapak I Dewa Gede Ardana, tokoh agama Hindu Desa Sunda Kelapa, 8 Agustus 2017 
"Desa Sunda Kelapa ini terdiri dari berbagai suku dan agama, tentunya saling menjaga batasan batasan budaya dan agama masing masing sangatlah penting, ${ }^{123}$

Pernyataan ini senada dengan bapak Pirmanto sebagai kepala desa Abu Sakim, beliau mengatakan: "Yang penting kita jaga budaya dan agama kita masing masing suapaya keamanan terjaga tidak ribut antar warga"24. Untuk menjaga keharmonisan dalam masyarakat tentunya nilai nilai trasisi, norma dan religi perlu di komunikasikan dengan bijaksana.

Tradisi merupakan adat kebiasaan yang diproduksi oleh diproduksi oleh masyarakat berupa aturan yang biasanya tidak tertulis tai dipatuhi oleh masyarakat, bagi yang melanggar aturan masyarakat ini akan mendapat sanksi masyarakat yang besifat sanksi sosial. Norma adalah tindakan apa yang harus dilakukan oleh masyarakat baik berupa larangan atau anjuran, sedangkan nilai adalah baik atau buruk yang dilakukan oleh masyarakat yang berkaitan dengan perilaku.

Setiap masyarakat memiliki sistem religi, yakni adanya kepercayaan manusia terhadap kekuatan yang dianggap lebih tinggi kedudukannya dari manusia. Maka manusia akan melaksanakan sistem religi yang dianggap media komunikasi dengan kekuatan gaib tersebut. Aktivitas religi ini sangat berkaitan erat dengan emosi keagamaan. Emosi keagamaan merupakan unsur penting dalam sistem religi, kebersamaan dengan sistem keyakinan dan sistem ritual keagamaan.

Dalam konteks komunikasi kebudayaan yang dimaksud adalah mempersoalkan dunia dan alam raya dan terciptanya dunia dan alam serta sistem kepercayaan dan gagasan tentang mitologi. Praktik ritual keagamaan diwujudkan dalam bentuk khas, seperti bertapa, puasa, zikir, bersemedi, bersaj, berkorban, berdo'a, tarian suci, nyanyian suci, berprosesi dengan pawai, seni drama dan lain sebagainya.

Praktik ritual keagamaan tetap dilaksankan secara baik dan harmonis di desa Abu Sakim dan Sunda Kelapa. Desa Abu Sakim mayoritas penduduk beragama Islam tentunya segala ritual keagamaan pun dilaksanakan sesuai dengan syari'at yang dianut. Dan umat kristenpun melaksanakan kebaktian setiap minggu sesuai dengan agama yang dianut.

Hal ini di kemukakan oleh bapak Edy Purnomo, "kami umat kristiani walaupun sedikit di desa ini tapi tidak pernah merasa dibalangi untuk melaksankan ritual keagamaan, kami kegereja setiap pagi minggu, ${ }^{, 25}$ Begitu juga yang disampaikan oleh umat Hindu, mereka melaksanakan ritual keagamaan sangat nyaman walaupun sebagian besar di desa Sunda Kelapa adalah umat Islam. Hal ini di kemukankan oleh bapak Wayan Sujana "kami umat bindu hampir setiap minggu ada vapacara

\footnotetext{
${ }^{23}$ Wawancara dengan Bapak Karyo, Kepala Desa Sunda Kelapa, 8 Agustus 2017.

${ }^{24}$ Wawancra dengan Bapak Pirmanto Kepala Desa Abu Sakim, 8 Agustus 2017.

${ }^{25}$ Wawan cara dengan Bapak Edy Purnama, tokoh agama Kristen Protestan, desa Abu Sakim, 7 Juli 2017
} 
agama, setiap malampun bersembahyang, kita disini sangat aman dan dapat menjalankan ritual keagamaan masing masing dengan baik, ${ }^{26}$

Umat islampun sebagai agama mayoritas di desa Abu Sakim dan Sunda Kelapa memiliki peran penting bagaimana mewujudkan rasa aman sesama umat menjalankan ritual agama masing masing. Seperti yang di sampaikan oleh ibu Mardianis: "kita melaksanakan urusan agama kita dengan "agamamu agamamu dan agamaku agamaku" itu saja jangan ikut campur agama orang lain"27 begitu juga kata ibu Rita Susianti:" kita laksankan agama kita dan jangan ikut campur dengan agama orang lain",28

\section{Proses komunikasi multikltural di desa Sunda Kelapa dan Abu Sakim}

Komunikasi multikutural merupakan proses komunikasi yang terjadi di dalam masyarakat yang berbagai suku, agama dan budaya. Dalam kehidupan masyarakat terjadi interaksi antara individu atau kelompok bahakan antar masyarakat. Proses komunikasi ini perlu difahami sesama individu agar tercipta ruang dan lingkungan yang harmonis. Masyarakat yang harmonis tentunya memerlukan interaksi atau pola hubungan yang sistem sistemnya berfungsi secara efektif.

\section{Interaksi Sosial}

Bentuk umum proses sosial adalah interaksi sosial yang juga dapat dinamakan proses sosial, karena interaksi sosial merupakan syarat utama terjadinya aktivitas-aktivitas sosial. Bentuk lain dari proses sosial hanya merupakan bentuk-bentuk khusus dari interaksi sosial, menurut Soerjono yang mengutip dari buku Gillin, “interaksi sosial merupakan hubungan-hubungan sosial yang dinamis menyangkut hubungan antara orang-orang-perorangan, antara kelompok-kelompok manusia, maupun antara orang perorangan dengan kelompok manusia"29. Dalam interaksi sosial terebut terdapat berbagai komponen yang mendukung terjadinya suatu interaksi sosial diantaranya yaitu:

Presepsi sosial adalah cara seseorang berfikir tentang orang lain. Dimana ketika seseorang tersebut berinteraksi dengan orang lain maka dai itu proses persepsi sosial sedang berlangsung. Sugeng menyatakan dalam bukunya yang mengutip dari buku Fisher beberapa prinsip persepsi sosial yang perlu diketahui diantaranya: pertama prinsip selectivity (penseleksian stimulus), tidak semua rangsangan yang diterima akan ditampung dengan baik oleh seseorang terkait stimulus yang didapatnya. Maka dari itu agar bisa mempersepsikan dengan baik

\footnotetext{
${ }^{26}$ Wawancara dengan bapak Wayan Sujana, tokoh agama Hindu desa Sunda Kelapa, 8 Agustus 2017.

27 Wawancara dengan ibu Mardianis, masyarakat Sunda Kelapa, beragama Islam, 8 Agustus 2017.

${ }^{28}$ Wawancara dengan ibu Rita Susianti, masyarakat desa Abu Sakim beragama Islam, 7 Juli 2017.

${ }^{29}$ Soerjono Soekanto, Sosiologi Suatu Pengantar, (Jakarta: Rajawali Pers, 2010), hal. 55
} 
seseorang harus melakukan seleksi rangsangan sehingga perhatiannya hanya tertuju pada elemen rangsangan tertentu saja. ${ }^{30}$

Proses persepsi ini tentunya akan mempengaruhi proses komunikasi yang dilakukan di desa Abu Sakim dan desa Sunda Kelapa, masyarakat yang berbeda suku dan agama tentunya memerlukan pemahaman yang baik, menurut beberapa orang informan mampu untuk mempersepsikan dengan baik proses komunikasi yang dilakukan seperti penuturan dari bapak Jamani:

"pemahaman akan pelaksanaan kegiatan yang ada di desa kami sangat perlu di lakukan karena akan ada persepsi yang berlainan agama dan suku, proses persepsi akan mempengarubi kegiatan masyarakat, 31

Begitu juga yang di ungkapkan oleh bapak Nicolous RTS: "Perlu sekali kita mempersepsikan apapun yang dilakukan oleh masyarakat secara baik, karena ini akan menjadikan perilaku kita bersama dalam masyarakat walaupun berbeda agama dan suke ${ }^{\prime 32}$

Masyarakat desa Sunda Kelapa dan Desa Abu Sakim yang multi agama dan multi budaya, tentunya akan sangat tergantung degan persepsi masyarakat terhadap agama dan budaya lainnya. Sebagaimana ungkapan kepala desa Sunda Kelapa:

"Sunda Kelapa ini mayoritas masyarakat beragama Islam, kemudian Hindu, ada juga kristen, dalam mempersepsikan apa yang disampaikan oleb warga, tentunya saya perlu dengan baik mencermati, agar tidak salah berkomunikasi,"33

Berdasarkan hasil wawancara yang tim lakukan di masyarakat desa Abu Sakim dan Sunda Kelapa, maka dapat digambarkan bahwa masyarakat di dua desa ini sangat berhati hati untuk mempersepsikan apapun kegiatan antar umat beragama agar tetap terjaga keharmonisan. Seperti pernyataan bapak I Gede Ardana:

"Disini banyak agama lain dan budaya juga berbeda, apapun yang kita lihat dan kita dengar jangan terlalu cepat berprasangka tidak baik",34

Masyarakat umat Hindu yang tim peneliti observasi lapangan pada saat mempersiapkan acara ulang tahun rumah ibadah. Tim peneliti melihat begitu sibuknya umat Hindu yang akan merangkai sesajian yang akan di gunakan dalam ulang tahun rumah ibadah tersebut.

Dalam proses interaksi ini akan terdapat juga persepsi yang akan di simpangkan. Kedua prinsip distorsi (penyimpangan) dimana dasar dari prinsip ini yakni seseorang cenderung melihat segala sesuatu yang ingin dilihatnya saja. Apabila ada suatu rangsangan yang tidak ingin dilihat maka seseorang tersebut cenderung men-distorsi-kan (menyimpangkan) rangsangan tersebut. ${ }^{35}$

\footnotetext{
${ }^{30}$ Sugeng Sejati, Psikologi Sosial Suatu Pengantar, (Yogyakarta: Teras, 2012), hal. 75

${ }^{31}$ Wawancara dengan bapak Jasmani, Tokoh Masyarakat desa Abu Sakim, 27 Juli 2017

${ }^{32}$ Wawancara dengan bapak Nicolous RTS, Masyarakat desa Sunda Kelapa, 27 Juli 2017

${ }^{33}$ Wawancara dengan Bapak Karyo, Kpala Desa Sunda Kelapa, 27 Juli 2017.

${ }^{34}$ Wawancara dengan bapak I Gede Ardana, Tokoh Agama desa Sunda Kelapa, 27 Juli 2017.

${ }^{35}$ Sugeng Sejati, Psikologi Sosial Suatu Pengantar, (Yogyakarta: Teras, 2012),, hal. 76
} 
Dalam proses berkomunikasi perlu adanya distorsi, untuk menghilangkan persepsi yang tidak ada gunanya. Seperti yang di kemukakan oleh bapak Karyo: "jika informasi yang di dengar atau peristiwa yang di lihat tidak ada gunanya bagi kita maka, tidak perlu di besar besarkan atau dibahas, lebih baik anggap tidak tahu"36

Sama seperti yang dikemukakan oleh bapak Pirmanto: “ jika ada laporan warga dan kita tindaklanjuti akan tetapi tidak jelas maka tidak perlu dibesar besarkan" ${ }^{37}$

Sama halnya dikemukakan oleh masyarakat, “38 jika ada yang kita lihat dalam ritual budaya dan agama orang lain serta tidak ada yang perlu kita lakukan untuk ikut serta atau menilai baik dan buruk, maka abaikan saja."

Dengan demikian masih berlakunya distorsi di masyarakat desa Sunda Kelapa dan desa Abu Sakim dalam hal untuk mempersepsikan apapun yang terjadi di masyarakat agar tetap terjaga kerukunan antar umat beragama.

Dalam proses distorsi tentunya di pengaruhi oleh motivasi yang dilakukan oleh masyarakat sdesa Abu Sakim dan Sunda Kelapa dalam interaksi sesama warga.

\section{Motivasi Sosial}

Motif adalah kondisi internal individu yang konsisten, dimana kondisi tersebut telah menyebabkan timbulnya suatu perilaku atau kecendrungan perilaku. Dalam hal ini motif sosial lebih tertuju pada keberadaan orang bukan pada lingkungan fisik. Misalnya lapar, merupakan motif psikologis, yang mana hal tersebut merupakan fungsi dari lingkungan ${ }^{39}$. Beberapa teori yang relevan dengan motif sosial tersebut diantranya ${ }^{40}$ :

Selanjutnya yakni teori Herarchy of Needs, yang diperkenalkan oleh Abraham Moslow yang dikuti oleh sugeng dalam buku Fisher. Menurut Moslow, manusia itu mempunyai lima kebutuhan dasar yang tersusun secara birarkhis (berurutan). Dimana kebutuhan yang pertama harus terpuaskan terlebih dahulu, sebelum ia mencapai kebutuhan kedua demikian pula seterusnya.

Kebutuhan-kebutuhan tersebut yakni kebutuhan fisik yang mendasar seperti makanan, minuman, sex dan udara. Kebutuhan kedua yakni keamanan artinya seseorang mempunyai kebutuhan untuk terhindar dari segala bahaya yang mengancam. Ketiga yakni rasa cinta, ingin dimiliki dan memiliki orang lain (belongingness). Keempat kebutuhan rasa harga diri (esteem needs). Dan kelima yakni kebutuhan aktualisasi diri yakni kebutuhan manusia yang tertinggi dimana manusia tersebut ingin merealisasikan segala potensi individu yag unik.

\footnotetext{
${ }^{36}$ Wawancara dengan Bapak Karyo, kepala desa Sunda Kelapa, 27 Juli 2017.

${ }^{37}$ Wawancara dengan Bapak Pirmanto Kepala Desa Abu Sakim, 28 Agustus 2017.

${ }^{38}$ Wawancara dengan Betti Herawati, ketua PKKRT Harapan Bunda, desa Sunda Kelapa, 28 Agustus 2017.

${ }^{39}$ Sugeng Sejati, Psikologi Sosial Suatu Pengantar, (Yogyakarta: Teras, 2012),, hal. 81

${ }^{40}$ Ibid, hal. 81-83
} 
Dalam kehidupan bermasyarakat desa Abu Sakim dan Sunda Kelapa memenuhi kebutuhan hidup dengan cara bertani, berniaga, tukang bahkan ada yang menjadi aparatur sipil negara seperti yang telah di sebutkan dalam deskripsi wilayah penelitian.

Pemenuhan kebutuhan hidup ini tentunya termotivasi dengan interaksi yang dilakukan namun terkadang terdapat kendala, misalnya dalam bercocok tanam dan berternak. Terkadang lahan pertanian berada di dekat perumahan penduduk, dan ternak pendudukpun mencari makan di sekitar wilayah pemukiman dan pertanian.

Beberapa kali tim peneliti survei dan wawancara dengan warga disebutkan adanya ternak warga yang memasuki wilayah pertanian akan tetapi bisa di selesaikan dengan baik dengan cara musyawarah mencapai mufakat, hal ini di kemukakan oleh tokoh adat desa: " jika ada ternak yang memasuki wilayah pertanian warga, maka yang memiliki ternak akan di minta untuk menganti rugi hasil tani yang di makan ternak tersebut dengan cara menghitung harganya, hal ini sudah menjadi kesepakatan antar desa ini" ${ }^{41}$ Dalam proses komunikasi multikultural ini perilaku yang terjadi dalam masyarakat dapat di pelajari antar warga melalui sosial learning.

\section{Social Learning}

Adalah proses perubahan perilaku yang melibatkan orang lain. Adapun elemen-elemen yang dibutuhkan proses tersebut berupa motivasi dimana seseorang memang ingin mengubahnya, association dan stimulus (rangsang) seseorang membutuhkan asosiasi (ada hubungannya) antara situasi learning dengan rangsangan yang membuat perubahan perilaku terjadi, serta reinforcement (penguatan) penentu perilaku yang diubah dan cara perubahan terjadi.

Beberapa teori yang berkaitan dengan social learning. ${ }^{42}$ tersebut di antaranya: teori the law of effect, dimana teori ini diperkenalkan oleh Thorndike mengatakan bahwa perilaku yang membawa akibat (efek) memuaskan akan cenderung diulangi lagi. Sebaliknya perilaku yang membawa akibat tak menyenangkan, maka cenderung tidak akan diulangi lagi. Jadi, efek (akibat) dari suatu perilaku akan menjadi penyebab terbentuknya perilaku selanjutnya.

Teori selanjutnya yakni yang dikuitp oleh Fisher yakni operant conditioning dari Skinner dimana suatu perilaku segera mendapat penguatan maka seseorang akan mempelajari perilaku tersebut.

Dalam sosial learning Sugeng menjelaskan terdapat cara lain untuk merubah perilaku selain diri seseorang itu sendiri. Seperti pernyataan Albert Bandura yang dikutip Sugeng menjelaska proses perubahan perilaku dapat terjadi dengan cara melihat pada orang lain (observational learning). Perihal seorang selalu

\footnotetext{
${ }^{41}$ Wawancara dengan Bapak Sri Widodo, tokoh adat desa Sunda Kelapa, 28 Agustus 2017.

${ }^{42}$ Sugeng Sejati, Psikologi Sosial Suatu Pengantar, (Yogyakarta: Teras, 2012),. 85-86
} 
mengamati semua perilaku orang lain (model), hal tersebut termasuk peguat (reinforcement) yang kemudian individu mengikutinya ${ }^{43}$.

Dimana menurut Bandura selanjutnya terdapat dampak tertentu kepada orang yang mengamatinya tersebut seperti: pertama, dampak acquisition (pencapaian, perolehan). Kedua, dampak (inhibilition atau disinhibition). Ketiga, response facilitation yakni pengungkapan respon yang sebenarnya sudah ada.

\section{Komunikasi multikultural dalam menjaga kerukunan antar umat beragama di desa Sunda Kelapa dan Abu Sakim}

Dalam masyarakat yang mejemuk terdapat berbagai kelompok masyarakat yang memiliki latar belakang adat istiadat, budaya, agama, dan kepentingan. Masyarakat majemuk adalah suatu masyarakat yang terdiri atas dua atau lebih elemen yang hidup sendiri-sendiri tanpa ada pembaruan satu dan lainnya dalam satu kesatuan politik.

Seperti yang ungkapkan oleh bapak Karyo: "desa Sunda Kelapa ini masyarakatnya sangat majemuk terdiri dari beberapa suku: ada Sunda, Jawa, Lampung, Bali, Palembang bahkan dari Bugis" "44 Dari observasi yang tim peneliti lakukan di desa Sunda Kelapa dan wawancara dengan warga, ada yang berasal dari Lampung, Jawa, dan Bali.

Begitu juga desa Abu Sakim yang merupakan daerah multikultural, seperti yang di sampaikan bapak Pirmanto: "desaAbu Sakim ini terdiri dari banyak suku, bahkan ada kampung Kedurang, ada dari Jawa, lampung, sulawesi, dan orang asli Bengkulu suku Lembak ${ }^{45}$,

Dengan observasi langsung di desa Abu Sakim dan Desa Sunda Kelapa, dua desa ini terlihat sangat beragam, di sepanjang perjalanan masuk desa Sunda Kelapa maka akan di temui Pura yang berada di depan rumah warga, setelah di lakukan wawancara mereka adalah transmigrasi dari Bali dan pernah tinggal di provinsi Palembang kemudian transmigrasi kembali di Bengkulu desa Sunda Kelapa $^{46}$.

Memasuki desa Abu Sakim di depan pintu gerbang terdapat Gapura desa Abu Sakim dan jika menelusuri jalan kita akan menemui beberapa keragaman budaya, agama dan suku. Terdapat 3 masjid dan 1 mushallah karena mayoritas agama di desa Abu Sakim adalah Islam dan terdapat pula ada tarekat AsSyidiqiyah. $^{47}$

${ }^{43}$ Sugeng Sejati, Psikologi Sosial Suatu Pengantar, (Yogyakarta: Teras, 2012),, hal. 91

${ }^{44}$ Wawancara dengan bapak Karyo, kepala desa Sunda Kelapa, 30 Agustus 2017.

${ }^{45}$ Wawancara dengan bapak Pirmanto, Kepala desa Abu Sakim, 30 Agustus 2017.

${ }^{46}$ Hasil observasi tim peneliti di desa Abu Sakim dan Sunda Kelapa, 25 Agustus 2017.

${ }^{47}$ Hasil observasi tim penelit di perkuat dengan hasil wawancara dengan bapak Pirmanto, kepala desa Abu Sakim: Tarekat ini menjalankan visi dan misinya untuk kesejateraan umat, di desa Abu Sakim akan ditemui bentuk rumah yang dibangun berdasarkan rasa persatuan dan memberikan bantuan kepada warga yang beragama Islam dengan beberapa persyaratan yang diajukan masyarakat diantaranya: warga yang akan di bangun rumah sederhana ini 
Keragaman merupakan salah satu realitas utama yang dialami masyarakat dan kebudayaan pada masa silam, kini dan pada waktu-waktu mendatang. Keragaman sering disikapi secara berbeda. Satu sisi diterima sebagai fakta yang dapat memperkaya kehidupan bersama, tetapi di sisi lain dianggap sebagai faktor penyulit. Kemajemukan dapat mendatangkan manfaat yang besar, tatapi dapat pula menjadi pemicu yang dapat merugikan masyarakat jika tidak dikelola dengan baik.

Keragaman manusia bukan brearti manusia itu bermacam-macam atau berjenis-jenis seperti halnya binatang dan tumbuhan. Keragaman manusia berarti setiap manusia memiliki perbedaan. Perbedaan itu ada karena manusia adalah makhluk individu yang setiap individu memiliki ciri-ciri khas tersendiri. Perbedaan itu ditinjau dari sifat-sifat pribadi, seperti sikap, watak, kelakuan, tempramen dan hasrat.

Selain makhluk individu, manusia juga makhluk sosial yang membentuk kelompok persekutuan hidup. Setiap kelompok persekutuan hidup manusia pun beragam. Masyarakat sebagai persekutuan itu berbeda dan beragam karena ada perbedaan, misalnya dalam hal ras, suku, agama, budaya, ekonomi, status sosial, jenis kelamin, daerah tempat tinggal dan lain-lain. Hal-hal demikianlah disebut sebagai unsur-unsur yang membentuk keragaman dalam masyarakat.

Konflik berasal dari kata confligere yang artinya saling mengejutkan. Konflik dapat diartikan sebagai pertentangan kepentingan oleh pihak yang berbeda. Konflik yang terjadi dalam masyarakat sesungguhnya hal yang wajar dan lumrah. Konflik dapat diolah menjadi sesuatu yang konstruktif (membangun) dan dapat pula destruktif (menghancurkan).

Sutrisno mengungkapkan dalam bukunya Yaya dkk, sejarah manusia adalah sejarah konflik sosial seiring dengan perubahan yang mengelilinginya. Oleh karena itu, tidak sepatutnya kita terlalu takut dengan konfli. Hidup tanpa konflik merupakan sesuatu yang utopis. Hanya manusia yang tidak realitis yang ingin malarikan dirinya dari hakikat hidup manusia yang penuh dengan konflik sosial $^{48}$.

Keragaman merupakan peristiwa dari wujud konflik sosial yang dapat diklasifikasikan dalam enam kelompok bentuk konflik sosial, antara lain konflik pribadi, konflik kelompok, konflik antarkelas sosial, konflik rasial, konflik politik, serta konflik budaya.

Budaya berkaitan erat dengan kebiasaan atau adat istiadat yang dianut oleh anggota masyarakat. Konflik budaya yaitu pertentangan yang terjadi dalam masyarakat disebabkan oleh adanya perbedaan budaya. Bentuk konflik ini terjadi pada penduduk yang pluralistik dengan latar belakang budaya yang

harus memiliki lahan yang akan di bangun. Lahan ini adalah milik pribadi warga tersebut, selanjutnya untuk membangun rumah sederhana itu dikeluarkan dari khas tarekat asSyidiqiyah.

48 Yaya Suryana dan Rusdiana, Pendidikan Multikultural Konsep, Prinsip, Implementasi, (Bandung: Pustaka Setia, 2015), hal. 7 
berbeda sehingga dapat menimbulkan pertentangan antara budaya yang satu dan lainnya. Selain itu, dapat pula terjadi pertentangan antara budaya daerah dan budaya yang berasal dari luar atau pertentangan budaya Barat dan Timur. Cara yang dapat digunakan dalam menghadapi konflik seperti yang dikemukakan Yaya dan Rusdian diantaraya:

1. Menghindar bukan berarti meninggalkan persoalan, melainkan memaksakan kehendak pribadi kepada orang lain, menyesuaikan diri dengan keinginan orang lain.

2. Mengadakan kompromi dengan pihak lain dan mengadakan kolaborasi dengan pihak lain. Dengan demikian, secara umum terdapat dua cara dalam menghadapi konflik, yaitu gaya menghindar dan gaya kolaborasi yang memiliki aspek positif dan negatif.

3. Peran Aktif, terdapat tiga peran yang dapat dilakukan dalam menghadapi konflik. Sebagai mediator dilakukan pada tahap berlangsungnya konflik. Sebagai fasilitator dan broken yang umumnya dilakukan pada fase 'pascakonflik' ketika 'pertempuran' dan 'benturan-benturan fisik' sudah menurun.

4. Mengurangi Konflik, agar dampak negatif dari adanya konflik sosial dapat dikurangi, konflik sosial harus diupayakan proses penyelesaiannya. Konflik dapat bersifat sementara yang dinamakan akomodasi, dapat pula bersifat mendasar dan permanen yang mengarah pada terbentuk serta terpeliharanya integrasi sosial.

5. Akomodasi Konflik. Akomodasi memiliki dua pengertian yaitu, sebagai proses merupakan usaha untuk meredakan pertentangan agar tercapai kestabilan dalam masyarakat. Sebagai keadaan adalah adanya keseimbangan dalam interaksi antarperseorangan atau antarkelompok, dalam kaitannya dengan kaidah yang berlaku di masyarakat.

\section{Cara menyelesaikan Konflik}

Terdapat beberapa cara penyelesaian konflik berdasarkan kebiasaan yang digunakan masyarakat untuk menyelesaikannya. Ada cara-cara dalam penyelesaian sebuah konflik tidak memerlukan banyak waktu dan tenaga dan ada pula dalam penyelesaian konflik menggunakan waktu yang lama dan menggunakan tenaga yang banyak.

Berikut cara untuk menyelesaikan konflik yang di kemukakan Yaya dan Rusdian yaitu: Konsoliasi, yang berarti perdamaian atau dengan cara berdamai. Mediasi, artinya perantara atau media berarti menggunakan orang ketiga sebagai perantara dalam penyelesaian konflik. Arbitrase artinya keputusan berarti melalui lembaga untuk memutuskan dan menyelesaikan konflik. Paksaan. Detente memiliki arti mengendorkan atau mengurangi ketegangan ${ }^{49}$.

\footnotetext{
49 Yaya Suryana dan Rusdiana, Pendidikan Multikultural Konsep, Prinsip, Implementasi, (Bandung: Pustaka Setia, 2015), 38-39
} 
Desa Abu Sakim dan Sunda Kelapa dalam memanajemen konflik ayang terdapat di masyarakat yang di temukan oleh tim peneliti berdasarkan observasi langsung dan waawancara seperti yang di ungkapkan oleh warga desa: "konflik disini hampir tidak untuk konflik agama dan budaya yang ada hanya jika ternak warga memakan tanaman warga lainnya, kesepakatan antar warga maka pemilik ternak menganti harga tanaman yang sudah rusak tersebut"

Begitu juga yang di sampaikan oleh ibu Mardianis: "konflik agama dan budaya tidak ada, yang ada hanya persoalan ternak memakan tanaman warga, kesepakatan warga pemilik ternak menganti rugi tanaman yang sudah dimakan dan rusak oleh ternak tersebut" 51

Ketika tim peneliti melakukan triangulasi dengan tokoh adat desa, bapak Sri Widodo membenarkan aturan tersebut: "iya, jika aada ternak yang memakan atau merusak lahan pertanian warga, maka pemilik ternak tersebut harus mengnati rugi jika di hargakan dengan rupiah jumlah kerugian",52

Dikonfirmasi dengan kepala desa Sunda Kelapa dan Abu Sakim, akan sama jawabannya: iya, konflik agama dan budaya tidak terjadi,yang ada konflik jika ada ternak masuk kelahan pertanian warga, tetapi kesepakatan antar warga, pemilik ternak menganti rugi kerusakan lahan"53 sama halnya yang di sampaikan oleh bapak Pirmanto: "kesepakatan antar warga jika ada ternak yang menganggu lahan warga, maka pemilik ternak harus menganti kerugian lahan tersebut"

\section{Strategi Komunikasi Multikultural}

Strategi merupakan perencanaan yang digunakan untuk memperoleh atau mendapatkan sesuatu, dengan menggunakan strategi harapan mencapai tujuan yang dituju dapat dengan mudah atau dengan cepat untuk dicapai. Strategi membutuhkan sebuah analisis yang sangat tajam, karena dalam strategi seseorang tersebut akan melihat dampak yang akan terjadi apabila yang dilakukannya nanti berhasil ataupun gagal.

Menurut Onong U. Effendy strategi pada hakikatnya adalah perencanaan (planning) dan manajemen (management) untuk mencapai suatu tujuan. Akan tetapi, untuk mencapai tujuan tersebut, strategi tidak berfungsi sebagai peta jalan yang hanya menunjukkan arah saja, melainkan harus mampu menunjukkan bagaimana taktik oprasionalnya ${ }^{55}$.

Dalam sebuah komunikasi sangat dibutuhkan strategi berkomunikasi yang baik, karena tujuan dari komunikasi itu sendiri yakni menyamakan persepsi atau

\footnotetext{
${ }^{50}$ Wawancara dengan ibu Rita Susianti, warga desa Abu Sakim, 25 Agustus 2017.

${ }^{51}$ Wawancara dengan ibu Mardianis, warga desa Sunda Kelapa, 25 Agustus 2017.

${ }^{52}$ Wawancara dengan Bapak Sri Widodo, Tokoh Afat desa Sunda Kelapa, 30 Agustus 2017.

${ }^{53}$ Wawancara dengan bapak Karyo, kepala desa Sunda Kelapa, 30 Agustus 2017.

${ }_{55}^{54}$ Wawancara dengan Bapak Pirmanto, Ke[ala desa Abu Sakim, 30 Agustus 2017.

55 Onong Uchjana Effendy, Ilmu Komunikasi Teori dan Praktek, (Bandung: Remaja Rosdakarya, 1999), hal. 32
} 
menyamakan makna pesan yang disampaikan oleh komunikator kekomunikan. Dengan strategi tersebut antara komunikator dan komunikan akan berupaya menggunakan strategi komunikasi mereka masing-masing mengikuti pola berkomunikasi diantara keduanya, agar pesan yang diterima dapat dengan mudah di fahami masing-masing dari mereka tersebut.

Dalam menjaga kerukunan antar umat beragama di Kecamatan Pondok Kelapa kabupaten Bengkulu Tengah, maka diperlukannya strategi komunikasi multikultural yang diterapkan oleh beberpa element masyarakat di desa Abu Sakim dan Desa Sunda Kelapa.

Dari beberapa agama yang ada di desa Abu Sakim dan desa Sunda Kelapa, sama sama menerapkan strategi komunikasi yang berupa planing dan manajemen. Planing ini sangat perlu karena harus di atur strateginya perencanaan agar kerukunan antar umat beragama tetap terjaga dengan baik, seperti yang di kemukanan oleh tokoh agama Hindu "kami saling menghormati, saling menghargai ${ }^{56}$ kita juga saling menjaga sikap antar umat". Jika ingin menjaga kerukunan antar umat beragama disini cukup dengan "lakum dii nukum wa ad-din",58." Dengan demikian kerukunan antar umat beragama di desa Abu Sakim dan Sunda Kelapa tidak terlepas dari semua unsur yang ada dalam masyarakat.

\footnotetext{
${ }^{56}$ Wawancara dengan bapak Wayan Sujana, Tokoh Agama Hindu, desa Sunda Kelapa, 11 Agustus 2017

57 Wawancara dengan Bapak I Dewa Gede Ardana, Tokoh Agama Hindu, desa Sunda Kelapa, 11 Agustus 2017.

${ }^{58}$ Wawancara dengan Bapak Sri Widodo, Tokoh Adat, desa Sunda Kelapa, 11 Agustus 2017.
}

A., Devito, Joseph. 1997. Komunikasi Antar Manusia. Jakarta: Profesional Books.

Hamidy, Badrul Munir. 1980. Disarikan dari buku sejarah orang melayu Bengkulu.

Larry A. Samovar dkk, Komunikasi Lintas Budaya Communication Between Cultures, (Jakarta: Salemba Humanika, 2010), hal. 28

M. Philip, Estelle and D.S. Pugh. 1994. How to Get Ph.D : A Handbook for students and Their Supervisor, Buckingham, Philadelphia, USA : Open University Press

Mohammad Shoelhi, 2015 Komunikasi Lintas Budaya, Bandung: Simbiosa Rekatama.

Morissan., 2013. Teori Komunikasi Individu Hingga Massa. Jakarta: Kencana.

Priandono, Tito Edy. 2016. Komunikasi Keberagaman. Bandung: Remaja.

Rakhmat, Jalaluddin. 2001. Psikologi Komunikasi. Bandung: Remaja Rosdakarya.

Ritzer, George dan Douglas J. Goodman. 2004 Teori Sosiologi Modern. Jakarta: Prenada Media.

Sejati, Sugeng. 2012. Psikologi Sosial Suatu Pengantar. Yogyakarta: Teras.

Soekanto, Soerjono. 1982, Sosiologi Suatu Pengantar. Jakarta: Rajawali Pers.

Uchjana Effendy, Onong. 1999. Ilmu Komunikasi Teori dan Praktek. Bandung: Remaja Rosdakarya.

W. Littlejohn, Sthepen. 1996. Theories of human communication. Wadhworth Publishing Company. Belmonth. 


\section{Penutup}

Berdasarkan hasil observasi, wawancara dan dokumentasi yang telah di triangulasi maka penelitian ini dapat disimpulkan sebagai berikut:

1. Komunikasi multikultural di Desa Sunda Kelapa dan Abu Sakim dalam Kajian Budaya dan Agama digunakan secara efektif oleh masyarakat.

2. Proses komunikasi multikltural di desa Sunda Kelapa dan Abu Sakim lebih mengunakan proses sensasi, persepsi, berfikir dan motivasi yang bijaksana agar kerukunan tetap bisa terjaga dengan baik.

Komunikasi multikultural dalam menjaga kerukunan antar umat beragama di desa Sunda Kelapa dan Abu Sakim lebeih mengedepankan toleransi umat beragama berupa saling menghargai, menghormati, menjaga, musyawarah mufakat dan tolong menolong.

\section{Daftar Pustaka}

A., Devito, Joseph. 1997. Komunikasi Antar Manusia. Jakarta: Profesional Books.

BPS Bengkulu Tengah, tahun 2016

Hamidy, Badrul Munir. 1980. Sejarah orang melayu Bengkulu.

Larry A. Samovar dkk, Komunikasi Lintas Budaya Communication Between Cultures, (Jakarta: Salemba Humanika, 2010), hal. 28

M. Philip, Estelle and D.S. Pugh. 1994. How to Get Ph.D : A Handbook for students and Their Supervisor, Buckingham, Philadelphia, USA : Open University Press

Mohammad Shoelhi, 2015 Komunikasi Lintas Budaya, Bandung: Simbiosa Rekatama.

Morissan., 2013. Teori Komunikasi Individu Hingga Massa. Jakarta: Kencana.

Priandono, Tito Edy. 2016. Komunikasi Keberagaman. Bandung: Remaja.

Rakhmat, Jalaluddin. 2001. Psikologi Komunikasi. Bandung: Remaja Rosdakarya.

Ritzer, George dan Douglas J. Goodman. 2004 Teori Sosiologi Modern. Jakarta: Prenada Media.

Sejati, Sugeng. 2012. Psikologi Sosial Suatu Pengantar. Yogyakarta: Teras.

Soekanto, Soerjono. 1982, Sosiologi Suatu Pengantar. Jakarta: Rajawali Pers.

Soekanto. 1982. Sosiologi suatu pengantar, Jakarta, Raja Grafindo Persada.

Soerjono Soekanto, Sosiologi Suatu Pengantar, (Jakarta: Rajawali Pers, 2010), hal. 55

Sthepen W Littlejohn, Theories of human communication, Wadhworth Publishing Company, Belmonth,1996, hal 16.

Sugeng Sejati, Psikologi Sosial Suatu Pengantar, (Yogyakarta: Teras, 2012), hal. 75

Uchjana Effendy, Onong. 1999. Ilmu Komunikasi Teori dan Praktek. Bandung: Remaja Rosdakarya.

W. Littlejohn, Sthepen. 1996. Theories of human communication. Wadhworth Publishing Company. Belmonth.

Yaya Suryana dan Rusdiana, Pendidikan Multikultural Konsep, Prinsip, Implementasi, (Bandung: Pustaka Setia, 2015), hal. 7 